The 'expat factor': The influence of working time on women's decisions to undertake international assignments in the oil and gas industry

Dr. Susan Shortland

Faculty of Business \& Law

London Metropolitan University

Old Castle Street

London

E1 7NT

UK

+ 44 (0) 2074230000 (tel)

email: $\underline{\text { s.shortland@londonmet.ac.uk }}$

Corresponding author: Dr. Susan Shortland

Acknowledgments: The author wishes to thank the three anonymous reviewers and the editor for their helpful input and assistance in refining this paper, and Laura Baker for her help in preparing the model. 


\title{
The 'expat factor': The influence of working time on women's decisions to undertake international assignments in the oil and gas industry
}

\begin{abstract}
This article examines the effect of working time on women's willingness to go on expatriate assignments in the oil and gas exploration and production sector. The research draws upon an analysis of two case study firms' international assignment and working time policies, semistructured interviews with 14 Human Resource staff responsible for policy design and implementation, and a survey of the views of 71 women expatriates, supported by in-depth interviews with 26 of the survey respondents. The research identifies an 'expat factor': assignees state that long hours are inherent in expatriation and necessary to further their careers. However in practice, working time is not excessive and flexible working practices are utilised. Hours of work have little effect on women's decisions to undertake long-term assignments but alternatives such as short-term and commuter assignments are unpopular as their working patterns are disruptive to family life. This article contributes to theory development by linking two discrete frameworks that explain women's career choices when they strive to balance their career goals with their families and by identifying a career compromise threshold when expatriation is rejected in favour of family considerations. A model is proposed to link working time/patterns to women's international assignment participation.
\end{abstract}




\section{Introduction}

As organisations globalise their operations and the notion of ' $24 / 7$ ' manufacture and delivery of goods and services becomes increasingly widespread, if not taken for granted, so the expectation of - and demand for - individuals to work longer hours, undertake different working patterns and to be accessible in any location becomes the norm. This is of particular relevance to organisational expatriation whereby individuals (and potentially their family) are transferred from their home country to work abroad by their employer (Cerdin and Le Pargneux, 2010; Howe-Walsh and Schyns, 2010). Expatriates are reported to work long hours and work intrusion has a strong impact on their family lives (Fischmayr and Kollinger, 2010; Shortland and Cummins, 2007). Practitioner surveys carried out annually or biennially by relocation management consultancies, such as Brookfield and Cartus, indicate overall growth in employer demand for international assignees year-on-year with sectors such as oil and gas standing out as major and increasing users of expatriates (Brookfield, 2009). Given this, under-represented groups such as women assignees, have become a focus for academic and practitioner research both generally (Altman and Shortland, 2008) and in industries such as mining and oil where their expatriate representation is particularly low (Shortland, 2009).

Thus far we know precious little about expatriates' actual hours of work, the influence these have on their assignment participation decisions and the effect of organisational policies and implementation practices on expatriates' working time such that they can manage both their work and family lives effectively and enjoyably. Set against this backdrop, the influence of working time within expatriate participation decision-making is a pertinent area for study. Given women's minority status as expatriates (Altman and Shortland, 2008; Hutchings, Lirio and Metcalfe, 2012), concern over their hours of work might be viewed as esoteric. Yet, it is of major 
importance. As demand for international mobility increases, a diversity paradox emerges: availability to undertake assignments is highest at early and late career stages, yet the cost of expatriation and experience required for it reduces employer demand for young expatriates and there are relatively few international positions for the most senior. The greatest volumes of expatriate positions require mid-career individuals - and it is precisely this group that is hindered in taking up international assignments through family demands (Dickmann and Baruch, 2011).

This research is set within the oil and gas exploration and production sector - an industry that places emphasis on the organisational expatriation of highly skilled and managerial personnel (Salt and Millar, 2006). On average, oil and gas firms' expatriate populations are around 7\% female (ORC Worldwide, 2007). Male-dominated organisations and occupations are reported as constrained by notions of standard working weeks and expectations of high and regular levels of overtime (Horrell and Rubery, 1991). For example, the use of rotational assignments, under which assignees transfer into and out of another country for a repeating set of short periods (BP, 2010) is a well-established feature of international mobility in the energy and mining sectors (Brookfield, 2011). This assignment type involves individuals working away from their families for example, on oil rigs or in remote locations, typically for two or four weeks on shift, working 12 hours a day, seven days a week, followed by a similar length rest period, off shift at home (Collings, Scullion and Morley, 2007). As such, while long hours of work on shift cannot be denied as they typically amount to 84 hours a week, the corresponding rest period results in working time averaging just half of this (i.e. 42 hours a week) over the rotation cycle. The oil and gas industry also makes use of other alternative assignment lengths and patterns such short-term assignments (typically around six months long) and commuter assignments (whereby the assignee travels regularly to and from the assignment location, leaving 
family members at home) in addition to traditional one to three year long-term assignments (Mayerhofer, Hartmann, and Herbert, 2004).

We currently do not know if there is a relationship between working time and willingness to undertake an expatriate role. Given the oil and gas industry's increasing demand for organisational expatriate assignments, its range of assignment types and patterns of international mobility, the indication that it potentially has a long hours' culture and that women's expatriate representation within it is low, this sector presents a fascinating context in which to address the research objective of examining the influence of working time on women's decisions to undertake expatriation.

\section{Literature review and theoretical framework}

While men can achieve their employment goals (potentially including expatriation) without necessarily losing a family life, women cannot so easily do so (Greenwood, 2001; Linehan and Walsh, 1999). Women's family and caring responsibilities place particular constraints upon their career decision-making resulting in 'compromise' (Corby and Stanworth, 2009) and/or 'satisficing' behaviour (Crompton and Harris, 1998a, 1998b). Satisficing refers to the actions taken by women who are unwilling to maximise career goals at the expense of family but wish to reach a high level in both. Satisficing can be effective in certain professions (for example, medicine) but is less so in industry at managerial levels where there is less opportunity to vary working hours and/or patterns to play an active part in raising children (Crompton and Harris, 1998b, 1999). Hence, it might be expected that expatriate roles with their long hours and requirements for international travel (Fischlmayr and Kollinger, 2010; Pascoe, 2005) - and 
international assignments in oil and gas exploration and production in particular given their remote locations and patterns of work - present few opportunities for satisficing.

Organisational expatriation is known to be financially attractive (Burnett and Von Glinow, 2011). Expatriates typically receive generous reward and benefits packages (see for example, Warneke and Schneider, 2011) enabling them to hire domestic help such as drivers, maids, nannies and so on (if these are not provided under policy) to save them time by undertaking household responsibilities and helping to raise children. This enables them to combine expatriate employment and family responsibilities. However, this is no substitute for spending time with their children. Hence, Crompton and Harris's principle of 'satisficing' offers a helpful theoretical framework in which to predict the effect of working time on women's expatriation participation decision-making, particularly for mothers. In addition, Anker's (2001) 'compensating differentials' model is relevant too. Anker posits that women 'prefer' occupations with working conditions and fringe benefits that enable them to interrupt their employment for child rearing over and above those offering high monetary reward (in this instance, expatriation). As such this model potentially offers a theoretical backdrop to help to explain the influence of working time on women's expatriation decisions, whether or not they currently have children. Flexible working initiatives (for example, flexitime, working from home and working reduced hours via part-time work and job sharing) together with managers' understanding of individuals' needs to balance their work and family responsibilities are reported as indicators of employer commitment to work-life balance in the Workplace Employment Relations Survey (Kersley et al., 2005). Of course, as Fleetwood (2007) notes, it is important not to assume flexible working policy and practice is directly linked to work-life or work-family balance. Nonetheless, organisational policy and programmes including flexible working interventions are 
viewed favourably by employees (Retna and Varatharju, 2010) and reported as having a positive effect on job satisfaction and perceptions of job quality (Kelliher and Anderson, 2008). However, requests to work flexibly can be seen as disruptive to work environments by managers particularly if these come from someone who supervises others (den Dulk and de Ruijter, 2008). Work-life balance can thus be seen as an issue for an individual to manage, rather than an organisational responsibility (Toth, 2005).

Long working hours and managerial cultures are perceived to conflict with parenting (Liff and Ward, 2001) and so work-life balance often becomes of greater significance once people have children (Kirton, 2011). While those with caring roles have obvious work-life conflicts, those without children may also experience conflict but are less able to legitimise it (Murphy and Doherty, 2011). The literature suggests that women experience greater work-life conflict through the persistence of embedded, gendered norms relating to the division of labour and family responsibilities (Crompton and Lyonette, 2005). So, although work-life balance is not just a women's issue (CIPD, 2010), it is more likely that women will take advantage of work-life balance interventions than men, linked to gender role expectations (Burnett, Gatrell, Cooper and Sparrow, 2010; Ismail and Ibrahim, 2008). This is especially the case in societies following cultural traditions and norms, such as in Asia (De Cieri and Bardoel, 2009).

While the unwritten rules of organisational culture criticise women who make use of family-friendly benefits, men are discouraged from taking them up (Gatrell and Cooper, 2008; Ruhe and Allen, 1997). Indeed, requests made by women to improve their work-life balance by working flexibly (for example, to undertake childcare which is seen as a woman's responsibility) are judged more favourably than those made by men (den Dulk and de Ruijter, 2008). Thus, women may be more likely to be granted flexible hours. However, this perceived benefit has 
considerable drawbacks. There is a danger that such initiatives imply women are inadequate and unable to compete on equal terms with men (Liff and Ward, 2001). Working flexibly creates lower visibility, resulting in disadvantage in performance and development reviews (Kelliher and Anderson, 2008) and women's career advancement and credibility are more likely to be affected negatively (Straub, 2007). It may therefore be argued that organisational interventions which set out to support work-life balance penalise women differentially (Peus and Traut-Mattausch, 2008).

Evidence appears mixed with regard to the outcomes of human resource policies and practices that support family-friendly management (Wood and de Menezes, 2010). For example, Perry-Smith and Blum (2000: 1107) suggest that organisations which have "extensive workfamily policies have higher perceived firm-level performance”. On the contrary, Ryan and Kossek (2008) note that gains such as developing an inclusive workplace expected from worklife policy implementation do not always come to fruition. Policies that support greater workplace flexibility, where they are in place, may be implemented differently where line managers have discretion over policy implementation (McCarthy, Darcy and Grady, 2010). They may receive only token support particularly when line managers with discretion over their implementation are untrained (Hyman and Summers, 2004). Indeed, de Menezes and Kelliher (2011) note that there appears to be little evidence to support a business case for flexible working.

In a host country expatriate environment, there is greater overlap of private and public life (Hearn, Jyrkinen, Piekkari and Oinonen, 2008). There is also tension between global working and family life generated through the need to work across time zones and communicate with remote colleagues outside of the host country's normal working day (Cappellan and 
Janssens, 2010). High levels of international travel are also cited as contributing to lengthy hours of work and expatriates are required to deliver results in recognition of the high costs of their assignments, be seen, and to lead by example (Shortland and Cummins, 2007). Not surprisingly, work interference with the family is higher than family interference with work (Fischlmayr and Kollinger, 2010). In addition, the literature suggests that the communication of organisational policy is generally found to be less satisfactory to expatriates than domestic employees (Bonache, 2005). It is therefore equally unsurprising that expatriates report limited awareness of organisational policies on flexible hours and work-life balance (Shortland and Cummins, 2007). Harris (2004) reports that expatriation presents clear and considerable work-life balance challenges with particular stresses experienced by female expatriates due to the combined effects of disruption to family roles, blurring of home and work boundaries and role and culture novelty. This would lead us to expect that working time will have an impact on women's decisions to take up an expatriate assignment. The principles of satisficing and compensating differentials support this theoretically, as they predict that women with children would wish to reach high levels in their careers but not at the expense of their families; and childless women who plan a family would choose careers which offer them working conditions that support interruption for child bearing and rearing. On this basis, expatriate careers with their documented pressures on working time and intrusion into family life may not appear viable nor be preferred.

Set within the theoretical frameworks of women's satisficing career choices (Crompton and Harris, 1998a, 1998b, 1999) and the principle of compensating differentials (Anker, 2001) this study sets out to address the following research questions within the industry context of oil and gas exploration and production: 
1. What effect does working time have on female expatriates' willingness to take up expatriate assignments?

2. Which aspects of organisational policy and practice influence women's decisions to accept an expatriate assignment and to what extent and why are these important to their expatriate participation?

\section{Method}

This research was carried out as part of a wider project examining the extent to which and how organisational policy and practice supported women's expatriation in the oil and gas exploration and production sector. The project proposal was presented to the members of the UK Oil and Gas Industry Peer Group. The HR International Assignments managers from two firms agreed to provide access to their female assignees and HR teams but neither would grant access to male expatriates nor host country line management due to resource pressures. With these cases being the only available, their selection and their HR and female expatriate populations represented a 'convenience' approach to sampling, (Saunders, Lewis and Thornhill, 2007). However, the firms were not global oil 'giants' and so were not considered to be unique or extreme cases meriting a single case study design (Yin, 2009); both were medium-sized companies. This was valuable to the research as they were considered to be representative of firms in this industry sector in terms

of their scale and location of operations. Company A operated in approximately 20 countries and had some 12,000 employees of whom $3 \%$ were expatriates. There were 27 female expatriates (8\% of its expatriate population). Company B's operations were in some 30 countries. It employed around 6,000 people of whom $10 \%$ were expatriates. It employed 66 female expatriates (11\% of its expatriate population). In both firms, the percentage of women expatriates 
exceeded the industry average of 7\% (ORC Worldwide, 2007). The two organisations employed around 300 rotational assignees; women comprised around $2 \%$ of these.

A triangulated research approach was undertaken with several independent data sources and data collection methods used to ensure validity (Saunders et al., 2007). Relevant organisational policies (such as those covering international assignments, work-life balance and flexible working) were collected from both firms and analysed; 14 HR professionals with responsibility for policy design and implementation were identified and interviewed; and a survey of all of the 93 female expatriate policy recipients was conducted by e-mail, supported by 26 in-depth assignee interviews.

The organisational policies were lengthy and detailed. To analyse this large volume of qualitative data, a process of 'data reduction' was necessary whereby policy components relevant to this research study were selected, abstracted and simplified (Miles and Huberman, 1994). The data were thus transformed into short, descriptive commentaries indicating the provision of support by assignment type. Further data reduction enabled the creation of summary tables covering working time, leave, flexible working and work-life balance provision in each case study firm (Table 1).

- Take in Table 1 about here -

These data were used in the construction of the survey questions. Participants were asked to record their weekly working hours and to note the importance of working time, leave and opportunities for flexible working to their expatriate participation (very important $=3$; important $=2$; not important $=1$ ). In addition, they were asked to record the importance of issues reported in the expatriate work-life balance literature such as working across time zones and international travel/commuting (Fischlmayr and Kollinger, 2010) as well as flexible working initiatives such 
as part-time working, job sharing and working at home (Kersley et al., 2005). (Details of the survey questions are given in the results tables as appropriate.) Survey participants were also asked to record their current assignment type.

The aim of the survey was to gain a picture of the extent to which organisational policy on working time and its practical implementation influenced women's decisions to undertake their current assignments. The survey data were also used to identify participants to be interviewed in order to gain an in-depth understanding of the working time issues underlying women's expatriate participation decision-making. The survey achieved a 76\% response rate: 19 responses from Company A (70\%) and 52 (79\%) from Company B. Of the 71 respondents, 51 were long-term assignees, 12 were on short-term assignments and/or graduate placements, five were on rotation, and three on extended international transfers.

The semi-structured interviews were conducted either face-to-face in the UK or by telephone where the interviewee was based abroad. The purpose was to examine how written organisational policies were implemented in the expatriate context. The assignees interviewed were selected using stratified sampling to ensure that certain characteristics of the expatriate population were not significantly under- or over-represented (Collis and Hussey, 2009). This was carried out by identifying and ensuring appropriate representation within the following strata: current type of assignment (pattern and length) and previous assignments undertaken; un/accompanied status; sending and current host locations; and job roles (see Table 2).

- Take in Table 2 about here -

The interviews with the HR experts took 30-90 minutes. They were asked whether and how working time and work-life balance policies applied to expatriates, main policy characteristics and who had benefited from them. Interviews with the women expatriates took 
between 60-90 minutes. Questions addressed whether their organisations had a long hours' culture; how their hours of work differed as an expatriate from those worked in the home country; how work-life balance was viewed in their host work location; whether they believed that they had an appropriate work-life balance; which forms of flexible working were the most helpful to them; and the extent to which their employer accommodated any requests they had made to work flexibly. Both the HR and assignees interviewed were asked to comment on working time and work-life balance in the context of the various assignment types offered so as to explore the implications for women's decisions to undertake expatriate careers against the theoretical backdrops of satisficing and compensating differentials.

The interviews were transcribed and analysed using NVivo 8. A list of codes was produced to create a 'template' that represented the themes identified in the qualitative data (King, 2004). The number of assignees and HR personnel who commented on each theme and the number of references that they made to it were recorded to ensure that the findings reported were representative and did not reflect the views of specific individuals.

\section{Findings}

The case study firms' international assignment policies recorded that host location working hours applied to long-term and short-term assignments; Company B's commuter assignments policy made similar provision. Rotational hours in both firms were stated as 84 per week (12 hours a day, seven days a week, for 28 days while on shift). HR personnel confirmed that these policies were implemented in the host countries but that non-standard hours to meet peaks and troughs in operations were undertaken. The assignees interviewed agreed that their working time might vary considerably from week to week. 
As shown in Table 3, long-term and short-term assignees in both firms worked an average of 47 hours a week and assignees on extended international transfers in the USA worked an average of 50. For those on rotation, the average weekly hours were 84, aligned with their contracts. However, these averages hid a wide range of normal weekly hours spent at work: between 39 to 60 for those on long-term assignments; between 40 and 55 for those on short-term assignments; between 42.5 and 55 for extended transfers and between 77 and 90 for those on rotation.

- Take in Table 3 about here -

\section{The 'expat factor'}

These data clearly show that not all of the expatriates in this study undertook long hours of work. Twelve assignees interviewed commented on working time at headquarters where " $a$ lot of people ... worked from seven until five ..." These hours were comparable to the long-term and short-term assignment averages. Given this, it is unsurprising that $72 \%$ of those surveyed said that working either local or additional hours in the assignment location were not important to their assignment participation and 68\% said undertaking international business trips involving extra hours of work were not important either (Table 4).

- Take in Table 4 about here -

Despite this, working long hours and having high workloads were identified as major themes in the assignee interviews; 23 and 14 interviewees representing both organisations commented on these two issues respectively, making hundreds of references to them. The key message from these assignees was that they worked in excess of their contractual hours, longer than local staff and longer than they would have done had they remained in their home country. They said that this "comes with the territory". When asked to explain the difference between 
organisational policy and their working time in practice, 19 of the assignees interviewed said that the answer simply lay in "being an expat". Disentangling the 'expat factor' brought out a variety of issues and explanations. Primarily these concerned costs and resources: expatriates were expensive and in limited supply. They reported experiencing implicit organisational pressure to take on greater responsibility and deliver more to justify the high allowances they received. Expatriates were also required to be "on call" and "to be seen" thereby sending an "appropriate message" in leading local staff. A range of other issues were cited as well including country and regional cultures, managing conference calls, meetings and information requests via the internet, working across time zones, and engaging in frequent business travel from the host location, reflecting the expatriate literature. Line managers (to whom the assignees reported directly and who were responsible for their performance review) also set expectations on working time and 16 assignees interviewed commented on this. In both organisations, those line managers who were described as "work addicts" expected similar behaviours from their expatriate staff. In regions headed up by "particularly obsessed executive vice presidents", long working hours were common.

The HR experts in Company B reported that long working hours were the norm for expatriates. They stressed the company's high performance culture and that bonuses depended on performance: "the expats were often doing 10 or 12 hour days and going in at the weekend ... phenomenal hours"; “... the head management team ... can be really driving, driving, driving”. In the main, Company B's assignees agreed with HR, their company had a long hours' culture although this did not generate negativity. For example: "I have personal expectations of performance and that means that I prioritise work willingly even if not necessarily pleasurably." However, recent changes in organisational policy on performance management had introduced 
recognition and reward for behaviours and pressure management training had been introduced for new line managers. These interventions appeared to mediate line managers' expectations of working time. Assignees reported that if a positive approach to working time was fostered at the top, it flowed down through the heads of the operations to locals and expatriates.

In contrast to the views of $\mathrm{HR}$ in Company $\mathrm{B}$, the HR representatives in Company $\mathrm{A}$ reported “... a good attitude towards working hours”; "in some of our cultures ... you are positively encouraged to go home”. Company A's assignees reported that “workaholics in upper management positions" were being replaced with top management committed to “... a positive work-life balance." Nonetheless, in the main, they agreed with assignees in Company B and said that they generally worked long hours.

Despite recognition of a change in line and senior managements' views over working time, the interviewees saw benefits to the 'expat factor'. They said that they wanted to prove themselves, to be seen as high performers, gain personal satisfaction, and to further their careers. They suggested the highly ambitious (expatriates and locals) would want to do this. Indeed, those working shorter hours were dissatisfied as they believed that this limited their career potential from undertaking expatriation. They reported being given "a lack of responsibility" and of not being "stretched". Bosses who "did not delegate" were criticised. The women reported that they "wanted to fix things" and to get their work done well to ensure good performance management and career outcomes. Expatriation offered good career potential and the assignees wanted to maximise this. However, this did not mean that long hours of work were irrelevant to their assignment participation per se. For example, being able to take home leave and rest and recreation leave in hardship locations was considered to be 'very important'. 
The assignment type was identified by both HR and assignees as an important issue. Unaccompanied assignments were not attractive; they brought the prospect of little else to do but work. Five unaccompanied long-term assignees interviewed said that they chose to work longer hours due to loneliness. This was echoed by those with experience of undertaking unaccompanied short-term and commuter assignments and rotational working. The 28 days off shift was viewed as a major benefit of rotational working. However, both the HR representatives and all bar one of the assignees interviewed believed that rotation was not an option for mothers of young children given the long periods of family separation.

Commuter assignments were viewed as especially disruptive to home life as they demanded foreign journeys at short notice, particularly impacting on mothers who said that they could not expect their employed partners to undertake childcare with little warning. Both HR and assignees said that the host countries which necessitated commuter and rotational assignments were very important to the companies' profiles and profits with consequent career benefits but few women assignees were willing to undertake them. This demonstrated satisficing decisionmaking as the women selected assignment types that meant they could combine their family and career roles to gain good outcomes for both but not the maximum career potential at the expense of their home life.

Fifteen assignees interviewed commented on weekend working. The need to work at weekends was common in functions where job requirements required $24 / 7$ production such as in engineering: “it's basically normal. I don't think about it”. Weekend working was also carried out by women in non-technical functions to manage workload peaks. While they were willing to accept this to some degree, they did not want it to become the norm. Demonstrating less acceptance of work intruding into their family time, the assignees with young children were 
unwilling to work weekends or in the evenings in the office, describing themselves as "pretty ruthless" about leaving on time and not working at the weekends unless "absolutely necessary". The potential damage to their careers of taking such actions was highlighted as potentially having "a detrimental effect". However, the assignees spoke frequently of working at home in the evenings, on activities such as reading and preparation, preferring this to late evening office work particularly if they had children. This suggested that assignees engaged in satisficing; they did the hours they needed but balanced these against ensuring quality time with their families.

The 'expat factor' appeared to be grade-related. Five mid-grade assignees commented that they thought that their working time would become too onerous if they were promoted, requiring unwelcome sacrifice to their personal lives. They indicated that senior level expatriate positions would not be attractive because of this and reported that very long hours of work would dissuade them from expatriating. Yet, the two assignees in the most senior grades in each firm (one of whom was married with accompanying children; the other single and unaccompanied) both reported that their working time was not that burdensome, being compensated by high levels of personal control.

\section{Flexible working}

Company B had a suite of policies that addressed flexible working patterns. Company A had no such written policies but applied similar practices to Company B. Flexible working and work-life balance, in the main, applied at headquarters or to local employees, seldom to expatriates on an official basis. As a result, relatively few assignees reported benefiting from these. That said unofficial arrangements were widespread and welcomed. The assignees interviewed reported that it was difficult to balance a demanding job with family life and having the ability to vary their hours of work either officially under policy or, more usually, unofficially by local arrangement 
when needed was highly valued. Flexible hours of work were popular with assignees on all types of assignments, but of greatest benefit to mothers and single women who had no one to deal with home-based issues. Assignees who participated in the nine day fortnights which operated officially in the US and informally in the Caribbean described them as "fantastic". This finding lends some support to the compensating differentials model by indicating women's desire for expatriate working conditions that enable them to interrupt their work roles when necessary. Taking time off for family emergencies was addressed in both firms' international assignment policies. This was 'very important' to $63 \%$ of the survey respondents in their assignment participation decision.

Of the survey respondents, $52 \%$ said that being able to work from home was 'not important' to their participation decision. However, working at home was reported as being popular, even though it was rarely possible. Assignees explained that many of the host locations had poor infrastructure, with housing not suitably equipped with technology to facilitate home working. In addition, this was not considered (both by assignees and HR) as being appropriate to lead local staff. However, expatriate housing was usually close to the workplace. This reduced commuting and facilitated spending more time with children. The five unaccompanied assignees welcomed opportunities to work in their home country by extending quarterly trips/home leave to spend more time with partners/families, although this was not officially sanctioned in policy.

The HR experts in both firms said that working part-time and job sharing were not career-contributing, did not apply or were only very rarely available to expatriates ; assignees agreed and said such arrangements were not important to their decisions to expatriate. The HR experts explained that co-working expatriates (where a dual career couple was employed by the same employer) could work part-time as the expatriate package would be applied to the full-time 
assignee while part-time employee would receive either a local salary or an expatriate salary (with no expatriate benefits) such that costs would not be prohibitive. Four of the assignees interviewed were currently co-working. One had asked to return 'part-time' following the birth of her child by working longer hours each day and using annual leave to support a four day working week; as such, she would still be on a full-time contract with no reduction in pay. Another assignee (with no children) reported having worked part-time, three days a week, in a previous expatriate co-working situation. In the main though, the assignees disagreed with HR; they said that either company policy or the type of work that they did precluded part-time work regardless of whether they were co-working.

Eight assignees expressed a desire to work part-time or return on this basis after maternity leave; one wanted to job share. A lack of part-time work opportunities was identified as a factor that might affect future take-up of expatriate roles when women became mothers, as well as a reason for current expatriates to give up their assignments and return home where they

could work part-time more easily. This suggests that mothers will satisfice to pursue other career opportunities and that they value roles with working conditions that enable them to vary their working time.

\section{Discussion and theory development}

While expatriation is viewed as career-enhancing and reaching the higher echelons of senior management is frequently associated with having undertaken international assignments and having first-hand global experience (Caligiuri and Colakoglu, 2007; Mendenhall, Kühlmann, Stahl and Osland, 2002; Orser and Leck, 2010), the extant literature paints a negative picture of the long hours of work associated with it (Fischmayr and Kollinger, 2010; Shortland and 
Cummins, 2007). However, in this study, assignees emphasised the positive outcomes of expatriate working time. Working longer than their contractual hours to ensure tasks were completed to the best of their ability was considered by the women assignees to be beneficial in terms of performance management outcomes and career progress. This research therefore adds to our knowledge by indicating that working additional hours as a result of the 'expat factor' is seen as beneficial to career growth, accepted by assignees as integral to expatriation, and deemed worthwhile if an international assignment is to fulfil career objectives.

Flexibility in working hours helps to ameliorate the effects of long hours of work (Cappellan and Janssens, 2010). Despite there being little evidence of organisational policy relating to flexible hours of work and/or work-life balance being applied to expatriates, this did not have a detrimental effect on women's willingness to expatriate. Assignees reported taking advantage of unofficial arrangements to fulfil their personal, domestic and family obligations and thus there appeared to be sufficient flexibility in their working arrangements to combine their work duties with demands in their private lives. Their one main area of concern related to being able to take time off for family emergencies but this was clearly addressed in organisational expatriate policy. In essence, expected favourable career outcomes and the ability to unofficially 'flex' working time to meet personal needs explain why assignees were not overly concerned over their working time.

The findings indicate mixed support for Anker's (2001) compensating differentials model which predicts women 'prefer' occupations with conditions and benefits (such as a good worklife balance) that help them to manage their family responsibilities over high monetary rewards. On the one hand, and in contrast to what the model would predict, the women assignees undertook highly-paid, career enhancing expatriation and said that they were not influenced by 
the working time requirements that potentially would suggest difficulty in managing their family lives. However, looking in more detail at this, a contradiction was revealed. There was evidence that the compensating differentials model could help to explain their choice of assignment type. The women mainly preferred to undertake long-term assignments as the working conditions associated with these (for instance, less frequent international business travel and less commuting) enabled them to accommodate family responsibilities more effectively with their career ambitions than did other assignment types. Alternative assignments (such as short-term, rotational and commuter arrangements) were seen as disruptive to family life, lonely given their unaccompanied status, and offered poor work-life and family balance, particularly for mothers. Relatively few women engaged with them.

Interestingly, these findings contrast with the extant literature which, for example, notes that short-term assignments can provide a pattern of work that enables women to balance international mobility with family and domestic roles (Demel and Mayrhofer, 2010; Harris and Dickman, 2005) and that commuter assignments can offer a high potential for assignment success and family life (Meyskens, Von Glinow, Werther and Clarke, 2009). While we know relatively little about female expatriates who undertake alternative types of assignments, Mayerhofer et al. (2004) do suggest that they would be likely to give them up in response to their personal and family life demands. We also know that repeated international business travel is stressful and tiring (Welch, Welch and Worm, 2007) and that organisational use of short-term and commuter assignments, rotational working and international business travel, while not a new phenomenon, is increasing (Brewster, Harris and Petrovic, 2001; Mayerhofer, Hartmann, Michelitsch-Riedl and Kollinger, 2004; Welch et al., 2007). In this study, rotational and commuter assignments in particular were rarely undertaken and those who did them did not have 
children. Although rotational contracts, in effect, provided six months off work each year and the rewards were excellent, the career and financial benefits were outweighed by the challenging working conditions and the lifestyle which engendered lengthy family separation. As such, the assignment type undertaken provides us with evidence in support of the compensating differentials model. In summary, the women in this study preferred good working conditions that enabled them to balance their family lives with their careers via long-term assignments to the even higher financial rewards that they could earn from alternative international assignment types such as rotation and international commuting used in remote, hostile and difficult locations.

We have only limited data on the effect of alternative assignment patterns on women's expatriation and hence their participation in these forms of international mobility is not fully understood (McKenna and Richardson, 2007). Examining women's participation in expatriation in the context of compensating differentials provides a new perspective to help us to understand their assignment type choices. In addition, women's strategies to combine long-term expatriation with their family responsibilities and how they managed their working time suggested that they had engaged in satisficing behaviour. They balanced their family and career demands and thus achieved the best outcomes as far as possible on both of these fronts (Crompton and Harris, 1998a, 1998b, 1999). While recognising that part-time work or job sharing were unlikely to be feasible in the expatriate environment, some assignees expressed their desire to work or return on a part-time basis after maternity leave, aligned to the literature that suggests that flexible hours are important to women returning to their careers after having children (Shaw, Taylor and Harris, 2000). This also points to women wishing to engage in satisficing. However, alternative assignment types are unlikely to offer a different course of action to part-time working. They are 
also unlikely to be able to help women to satisfice by striking an appropriate balance between their career and their family goals. This is particularly so given their unaccompanied nature and the stressful lifestyle created through inherent frequent travel (Shortland, 2009). These issues further reinforce the long-term assignment as the preferred assignment type.

Besides being unwilling to undertake assignment types that involved working time/patterns that affected their family life negatively, the women in this study were keen, in the main, only to work the hours needed to further their careers up to and including mid-grade level. The prospect of undertaking the lengthy hours of work that they (wrongly) believed were required in senior expatriate roles was perceived as too onerous. This study thus shows that women assignees do engage in career compromise as suggested by Corby and Stanworth (2009). However, it also demonstrates new knowledge by indicating that women compromise their careers when they experience a 'threshold' that they perceive to represent unacceptable hours and/or patterns of working time.

Refinement and linking of the principles of compensating differentials, satisficing and career compromise with working time/patterns is thus helpful to theory development in understanding women's choices in balancing their expatriate careers and family lives. The findings from this research indicate that there are two 'career compromise thresholds', taking effect in early and mid-career. At these threshold points, the principle of compensating differentials 'kicks-in' (good working conditions outweigh highly paid, career-enhancing expatriation) and satisficing 'tops out' (it is no longer possible to balance good career and family outcomes; career maximisation becomes damaging to family life). At these thresholds, perceive that it will no longer be feasible to achieve a good balance between career and family outcomes, aligned to the principle of satisficing, so they opt out of expatriation (or particular types of 
assignments), 'compromise' their careers in so-doing, but 'preferring' or 'prioritising' working conditions that put their family life first. This is depicted diagrammatically in Figure 1.

- Take in Figure 1 here -

Figure 1 shows that women's expatriate career decisions are underpinned by their desire to obtain good career and family outcomes as explained by the principle of satisficing. Engagement in expatriation also rests on the working conditions offered via the type of assignment available, as explained by the principle of compensating differentials. Two career compromise thresholds are depicted that predict when women will reject an international assignment based upon these principles. At the early career compromise threshold, if the working conditions offered by the assignment type are considered to be too detrimental to family life, expatriation will be rejected. This is most likely to be reflected in a refusal to undertake alternative types of assignments. If career and family outcomes can both be achieved, women accept expatriation and pursue career growth in junior and mid-grade expatriate roles undertaking a variety of assignment types if these are compatible with their family situations, although preferring long-term assignments which are seen as giving the best career/family balance. They engage in satisficing behaviour to achieve the best outcomes from their careers and their families, preferring not to maximise one at the expense of the other.

If working time/patterns become damaging to, or incompatible with, family life as women's expatriate careers progress, a second mid-career compromise threshold is reached. Women then reassess and rebalance their career/family outcomes. For instance, when they become mothers or have other family responsibilities, women who previously had undertaken alternative types of assignments opt out of them, even if this results in career damage. If they view the hours of work required to pursue senior expatriate careers as too onerous they do not 
seek senior expatriate positions either (even if these are via long-term assignments), again limiting their career progression via international mobility. These career compromise thresholds linked to working time/patterns thus act as filters, creating a 'bouncing out' effect and thereby reducing down the numbers of women assignees who hold senior or alternative assignment positions.

\section{Implications for practice}

While this study does not address men's expatriation, it does show that for women to take up international assignments a balance is needed between career and family outcomes. Unaccompanied assignments tend to lead to long working hours but support in policy via home leave, quarterly flights and 'flex' in work location to enable assignees to work in their home country for limited periods could help to encourage women's take-up of long-term unaccompanied assignments. Allowing accompanied mobility could help to encourage them to take-up short-term assignments. Flexibility in shift patterns, enabling assignees to 'flex' what appears to be fixed shift periods to balance them with their personal needs, could make rotational assignment patterns more attractive. More regularity in, or advance notice of, international travel could assist in making commuter assignments more feasible and attractive to women.

Line manager support for working at home when possible, arrangements to work parttime for co-working couples and the proximity of expatriate housing to the worksite can be highlighted in organisational policy. Even with limited official policy provision on flexible hours, if publicity is given to the opportunities available to undertake flexible working (unofficially or through policy), a more transparent picture of expatriate life could encourage women to consider such a career. 
The role of HR is particularly important in the development of flexible working in response to work-family issues (Milliken, Martins and Morgan, 1998). Nonetheless, organisations must be mindful that policy design alone is insufficient and, as Lewis, Gambles and Rapoport (2007) point out, a workplace mind-set change is necessary to ensure that any such policies are implemented in practice. It is also important that any policy on working time arrangements applied to expatriates aligns with local practice if expatriates' roles in leading local staff are not to be undermined.

\section{Limitations and directions for future research}

This research examines the importance of working time issues to women's expatriate participation decisions. Given that access was only given to female assignees, we do not know if these findings relate to women alone or are shared by their male counterparts. However, job design in overseas postings is known to be of particular significance to women's job satisfaction (Culpan and Wright, 2002). It is not inconceivable that alternative working patterns could be accommodated such that individuals (men and women) might perceive expatriation as a way of achieving balance between work and personal/family life (Cerdin and Le Pargneux, 2010).

Further research is needed in respect of how working time affects male expatriates' decisions to undertake expatriation to determine whether the findings here are representative of men and women or are gendered. A comparative study of men's and women's experiences of expatriate working time and work-life balance, how these are supported through organisational policy and practice and their effects on assignment participation via a variety of assignment types could also prove most useful in organisational policy design aiming to facilitate and support 
international mobility. Such research might also aid understanding of gender differences in assignment take-up with a view to increasing expatriate diversity in the future.

This research was based in two medium-sized oil and gas exploration and production organisations. As policy initiatives and practice interventions may vary across other industry groups and by size of organisation, any sector/firm size effects on policy design and implementation requires further research to establish their influence on expatriate participation. Further research is therefore needed in other industry sectors and in organisations of different sizes to determine the generalisability of these findings in respect of women's willingness to undertake expatriation linked to working time/patterns.

The survey conducted here resulted in a high response rate leading to confidence in the findings being representative of the female expatriate population. Nonetheless, had the sample size been larger and less skewed towards participation in long-term assignments, more detailed statistical analysis could have been conducted. While women expatriates remain a minority, their numbers have increased (Shortland and Altman, 2011). Thus, although it is recognised that extending sample sizes may well be not without its difficulties, this should not negate efforts to obtain larger samples in future research. Future research also could benefit from more detailed study of the effect of assignment type on expatriate participation to discover whether alternatives to traditional long-term assignments might provide more opportunities for women to undertake expatriation. In addition, longitudinal research into the changing nature of assignment lengths and patterns on women's expatriate participation linked to working time/patterns and work-life balance considerations would be valuable.

This research focused on organisational expatriation. Women's involvement in selfinitiated expatriation is equal to men's, contrasting with their participation in organisational 
assignments (Tharenou, 2009). This may be because the former provides greater flexibility for women to determine their working patterns which they are less able to do via organisational assignments. Further research comparing and contrasting the influence of working time arrangements on women's willingness to undertake self-initiated expatriation compared with organisational expatriation would therefore also prove to be a fruitful line of enquiry.

This study drew attention to theoretical frameworks that help to explain women's decisions when undertaking an expatriate career linked to working time and family balance. Further research into women's expatriation set within the context of satisficing, compensating differentials and career compromise, exploring how these concepts are inter-linked, could help us to understand in more depth expatriate gender diversity and how to improve it in future.

\section{Conclusions}

This study reaffirms our familiarity with the fact that expatriation typically involves working long hours but it also provides us with a new perspective. Women assignees attributed their lengthy working time to the 'expat factor' (working across time zones, undertaking international business trips, being seen to lead local staff and so on) aligning with the extant literature. However, while they were keen to report on their lengthy working time, their hours of work were not, in fact, overly excessive. Indeed, their average working time equated broadly with some of their non-expatriate colleagues at head office and in other company locations. The need to work relatively, but not excessively, long hours while on assignment was considered to be career enhancing. Indeed, women expatriates expected to work additional hours if they were to gain the maximum career benefits from their postings. As such, longer hours of work and the potential for lower levels of work-life balance did not present major deterrents to expatriation. However, 
women's willingness to engage in international assignments was set against their desire to balance their careers with their family lives, making the most of both as far as possible. To achieve both good career and family outcomes, they favoured taking up long-term assignments. Women associated poor family outcomes with alternative assignment types such as short-term, commuter and other unaccompanied patterns of deployment; as such, these forms of expatriation were unattractive and unpopular, even if they offered good career potential. Women preferred to engage in career compromise rather than in these types of international mobility. Senior expatriate appointments were also believed to require unreasonably long hours of work. Even though this was not the reality, the perceived long hours associated with senior grade expatriation and its potential effect on their family lives reduced its appeal, also leading to career compromise.

This paper provides a new theoretical contribution by proposing a link between the principles of satisficing, compensating differentials and career compromise. Women assignees attempt to gain the best career and family outcomes via satisficing, rather than maximising their careers at the expense of their families. They are willing to undertake highly paid expatriate careers and do not, as a matter of course, reject these in order to prioritise good working conditions that enable them to raise their families as might be predicted by compensating differentials. However, women do assess the working hours and patterns associated with different assignment types. They reject those which could provide good career outcomes if they believe that the working conditions will damage their family life.

In essence, while career outcomes dependent upon working time/patterns are perceived as (or are) attractive and these can be balanced with quality family outcomes, expatriation will be undertaken and satisficing takes place. When career outcomes dependent upon working 
time/patterns are perceived to (or actually) damage family outcomes, compensating differentials become relevant and a career compromise threshold takes effect. At this point women place priority on their family life and reject international assignments even if these have high career potential. Thus, although working time and work-life balance may not be cited directly by women as issues of importance that influence their assignment participation, hours of work and patterns of mobility can and do act as filters to women's international assignment participation. Organisational support to enable assignees to balance their careers and family lives, championed by top management, is therefore set to increase in importance if assignees are to be encouraged to undertake alternative assignment types and if employers are to source their future expatriates from a wider talent pool including women and those returning after having children.

\section{References}

Altman, Y., and Shortland, S. (2008), 'Women and international assignments: taking stock - a 25 year review', Human Resource Management, 42, 2, 199-216.

Anker, R. (2001), 'Theories of occupational segregation by sex: an overview', in Women, Gender and Work: What is Equality and How Do We Get There?, ed. M.F. Loutfi, Geneva: International Labour Organization, 129-155.

Bonache, J. (2005), 'Job satisfaction among expatriates, repatriates and domestic employees: the perceived impact of international assignments on work-related variables', Personnel Review, 34, $1,110-124$. 
BP. (2010), 'Global expatriate, rotator and flexible roles'.

$\underline{\text { www.bp.com/sectiongenericarticle.do?categoryId }=9017600 \& \text { contentId }=7032697}$

Brewster, C., Harris, H., and Petrovic J. (2001), 'Globally mobile employees: Managing the mix', Journal of Professional Human Resource Management, 25, 11-15.

Brookfield. (2009), International mobility: impact of the current economic climate, Chicago, IL: Brookfield Global Relocation Services.

Brookfield. (2011), Global relocation trends: 2011 survey report, Chicago, IL: Brookfield Global Relocation Services.

Burnett, S.B., Gatrell, C.J., Cooper, C.L., and Sparrow, P. (2010), 'Well-balanced families?: A gendered analysis of work-life balance policies and work family practices', Gender in Management: An International Journal, 25, 7, 534-549.

Burnett, M., and Von Glinow, M.A. (2011), 'Total rewards in the international context', in International Human Resource Management, eds. A-W. Harzing and A.H. Pinnington, London: Sage, 468-503.

Caligiuri, P.M., and Colakoglu, S. (2007), 'A strategic contingency approach to expatriate assignment management', Human Resource Management Journal, 17, 4, 393-410. 
Cappellan, T., and Janssens, M. (2010), 'Characteristics of international work: narratives of the global manager', Thunderbird International Business Review, 52, 4, 337-348.

Cerdin, J.-L., and Le Pargneux, M. (2010), 'Career anchors: a comparison between organizationassigned and self-initiated expatriates', Thunderbird International Business Review, 52, 4, 287299.

CIPD. (2010), 'Work-life balance'.

www.cipd.co.uk/subjects/health/worklifebalance/worklifeba.htm

Collings, D.G., Scullion, H., and Morley, M.J. (2007), 'Changing patterns of global staffing in the multinational enterprise: Challenges to the conventional expatriate assignment and emerging alternatives', Journal of World Business, 42, 198-213.

Collis, J., and Hussey, R. (2009), Business Research: A Practical Guide for Undergraduate and Postgraduate Students, Basingstoke, UK: Palgrave Macmillan.

Corby, S., and Stanworth, C. (2009), 'A price worth paying? Women and work - choice, constraint or satisficing', Equal Opportunities International, 28, 2, 162-178.

Crompton, R., and Harris, F. (1998a), ‘Explaining women's employment patterns: ‘orientations to work' revisited', British Journal of Sociology, 49, 1, 118-136. 
Crompton, R., and Harris, F. (1998b), 'Gender relations and employment: the impact of occupation', Work, Employment \& Society, 12, 2, 297-315.

Crompton, R., and Harris, F. (1999), 'Gender attitudes and domestic labour', in Restructuring Gender Relations and Employment: The Decline of the Male Breadwinner, ed. R. Crompton, Oxford, UK: Oxford University Press, 105-127.

Crompton, R., and Lyonette, C. (2005), 'Work-life 'balance' in Europe, GeNet 2005-10', www.genet.ac.uk/workpapers/index.html

Culpan, O., and Wright, G.H. (2002), 'Women abroad: getting the best results from women managers'. International Journal of Human Resource Management, 13, 5, 784-801.

De Cieri, H., and Bardoel, A. (2009), 'What does 'work-life management' mean in China and Southeast Asia for MNCs?' International Journal of Human Resource Management, 12, 2, 179196.

de Menezes, L.M., and Kelliher, C. (2011), 'Flexible working and performance: a systematic review of the evidence for a business case', International Journal of Management Reviews, 13, $4,452-474$. 
Demel, B. and Mayrhofer, W. (2010), 'Frequent business travellers across Europe: Career aspirations and implications', Thunderbird International Business Review, 52, 4, 301-311.

den Dulk, L., and de Ruijter, J. (2008), 'Managing work-life policies: disruption versus dependency arguments. Explaining managerial attitudes towards employee utilization of worklife policies', International Journal of Human Resource Management, 19, 7, 1222-1236.

Dickmann, M., and Baruch, Y. (2011), Global Careers, Abingdon, UK: Routledge.

Fischlmayr, I.C., and Kollinger, I. (2010), 'Work-life balance - a neglected issue among Austrian female expatriates', International Journal of Human Resource Management, 21, 4, 455487.

Fleetwood, S. (2007), 'Why work-life balance now?' International Journal of Human Resource Management, 21, 4, 455-487.

Gatrell, C. J., and Cooper, C. L. (2008), 'Work-life balance: working for whom?', European Journal of International Management, 2, 1, 71-86.

Greenwood, A.M. (2001), 'Gender issues in labour statistics', in Women, Gender and Work: What is Equality and How Do We Get There?, ed. M.F. Loutfi, Geneva: International Labour Organization, 69-84. 
Harris, H. (2004), 'Global careers. Work-life issues and the adjustment of women international managers', Journal of Management Development, 23, 9, 818-832.

Harris, H. and Dickmann, M. (2005), International Management Development, London: CIPD.

Hearn, J., Jyrkinen, M., Piekkari, R., and Oinonen, E. (2008), “'Women home and away”: transnational managerial work and gender relations', Journal of Business Ethics, 83, 41-54.

Horrell, S., and Rubery, J. (1991), 'Gender and working time: an analysis of employers' working-time policies', Cambridge Journal of Economics, 15, 4, 373-391.

Howe-Walsh, L., and Schyns, B. (2010), 'Self-initiated expatriation: implications for HRM', International Journal of Human Resource Management, 21, 2, 260-273.

Hutchings, K., Lirio, P., and Metcalfe, B.D. (2012), 'Gender, globalisation and development: a re-evaluation of the nature of women's global work', International Journal of Human Resource Management, 23, 9, 1763-1787.

Hyman, J., and Summers, J. (2004), 'Lacking balance? Work-life employment practices in the modern economy', Personnel Review, 33, 4, 418-429. 
Ismail, M., and Ibrahim, M. (2008), 'Barriers to career progression faced by women: evidence from a Malaysian multinational oil company', Gender in Management: An International Journal, 23, 1, 51-66.

Kelliher, C., and Anderson, D. (2008), 'For better or for worse? An analysis of how flexible working practices influence employees' perceptions of job quality', International Journal of Human Resource Management, 19, 3, 419-431.

Kersley, B., Alpin, C., Forth, J., Bryson, A., Bewley, H., Dix, G., and Oxenbridge, S. (2005), Inside the Workplace: First Findings From the 2004 Workplace Employment Relations Survey, London: Crown Copyright, Department of Trade and Industry/Economic and Social Research Council/Advisory, Conciliation and Arbitration Service/Policy Studies Institute.

King, N. (2004), 'Using templates in the thematic analysis of text', in: Essential Guide to Qualitative Methods in Organizational Research, eds. C. Cassell and G. Symon, London: Sage, 256-270.

Kirton, G. (2011), 'Work-life balance: Attitudes and expectations of young black and minority ethnic graduates', in Equality, Inequalities and Diversity: Contemporary Challenges and Strategies, eds. G. Healy, G. Kirton and M. Noon, Basingstoke, UK: Palgrave Macmillan, 252269. 
Lewis, S., Gambles, R., and Rapoport R. (2007), 'The constraints of a 'work-life balance’ approach: an international perspective', International Journal of Human Resource Management, $18,3,360-373$.

Liff, S., and Ward, K. (2001), 'Distorted views through the glass ceiling: the construction of women's understandings of promotion and senior management positions', Gender, Work and Organization, 8, 1, 19-36.

Linehan, M., and Walsh. J.S. (1999), 'Senior female international managers: breaking the glass border', Women in Management Review, 14, 7, 264-272.

Mayerhofer, H., Hartmann, L.C., and Herbert, A. (2004), 'Career management issues for flexpatriate international staff', Thunderbird International Business Review, 46, 6, 647-666.

Mayerhofer, H., Hartmann, L.C., Michelitsch-Riedl, G., and Kollinger, I. (2004), 'Flexpatriate assignments: A neglected issue in global staffing', International Journal of Human Resource Management, 15, 8, 1371-1389.

McCarthy, A., Darcy, C., and Grady, G. (2010), 'Work-life balance policy and practice: understanding line manager attitudes and behaviors', Human Resource Management Review, 20, $158-167$. 
McKenna, S., and Richardson, J. (2007), 'The increasing complexity of the internationally mobile professional: Issues for research and practice', Cross Cultural Management, 14, 2, 307320.

Mendenhall, M.E., Kühlmann, T.M., Stahl, G.K., and Osland, J.S. (2002), 'Employee development and expatriate assignments', in The Blackwell Handbook of Cross-Cultural Management, eds. M.J. Gannon and K.L. Newman, Oxford, UK: Blackwell Publishers, 155-183.

Meyskens, M., Von Glinow, M.A., Werther, W.B., and Clarke, L. (2009), 'The paradox of international talent: Alternative forms of international assignments', International Journal of Human Resource Management, 20, 6, 1439-1450.

Miles, M.B., and Huberman, A.M. (1994), Qualitative Data Analysis: An Expanded Source Book, London: Sage.

Milliken, F.J., Martins, L.L., and Morgan, H. (1998), 'Explaining organizational responsiveness to work-family issues: the role of human resource executives as issue interpreters', Academy of Management Journal, 41, 5, 580-592.

Murphy, F., and Doherty, L. (2011), 'The experience of work life balance for Irish senior managers', Equality, Diversity and Inclusion: An International Journal, 30, 4, 252-277. 
ORC Worldwide. (2007), 2006 Worldwide Survey of International Assignment Policies and Practices, New York, NY: ORC Worldwide.

Orser, B., and Leck, J. (2010), 'Gender influences on career success outcomes', Gender in Management: An International Journal, 25, 5, 386-407.

Pascoe, R. (2005), 'Enriching work and life in the global workplace', Workspan, 48, 10, 40-43.

Perry-Smith, J.E., and Blum, T.C. (2000), 'Work-family human resource bundles and perceived organizational performance', Academy of Management Journal, 43, 6, 1107-1117.

Peus, C., and Traut-Mattausch, E. (2008), 'Manager and mommy? A cross-cultural comparison', Journal of Managerial Psychology, 23, 5, 558-575.

Retna, K.S., and Varatharju, U. (2010), 'Effectiveness of quality work life balance programmes: employees' perceptions', International Journal of Quality and Innovation, 1, 2, 97-111.

Ruhe, J.A., and Allen, W.R. (1997), 'Preparing women for careers in international management', Journal of Education for Business, 72, 5, 278-283.

Ryan, A.M., and Kossek, E.E. (2008), 'Work-life policy implementation: breaking down or creating barriers to inclusiveness?', Human Resource Management, 47, 2, 295-310. 
Salt, J., and Millar, J. (2006), 'Foreign labour in the United Kingdom: Current patterns and trends', Labour Market Trends, October, 335-355.

Saunders, M., Lewis, P., and Thornhill, A. (2007), Research Methods for Business Students, Harlow, UK: Pearson Education.

Shaw, S., Taylor, M., and Harris, I. (2000), 'Jobs for the girls: a study of the careers of professional women returners following participation in a European funded updating programme', Career Development International, 5, 6, 295-300.

Shortland, S. (2009), 'Gender diversity in expatriation: Evaluating theoretical perspectives'. Gender in Management: An International Journal, 24, 5, 365-386.

Shortland, S., and Altman, Y. (2011), 'What do we really know about corporate career women expatriates?', European Journal of International Management, 5, 3, 209-234.

Shortland, S., and Cummins, S. (2007), 'Work-life balance: expatriates reflect the international dimension', Global Business and Organizational Excellence, 26, 6, 28-42.

Straub, C. (2007), 'A comparative analysis of the use of work-life balance practices in Europe. Do practices enhance female' career advancement?', Women in Management Review, 22, 4, 289304. 
Tharenou, P. (2009), 'Self-initiated international careers: Gender differences and career outcomes', in Maintaining Focus, Energy, and Options over the Career, eds. S.G. Baugh and S.E. Sullivan, Charlotte, NC: Information Age Publishing, 198-226.

Toth, H. (2005), 'Gendered dilemmas of the work-life balance in Hungary', Women in Management Review, 20, 5, 361-375.

Warneke, D., and Schneider, M. (2011), 'Expatriate compensation packages: What do employees prefer?', Cross Cultural Management: An International Journal, 18, 2, 236-256.

Welch, D.E., Welch, L.S., and Worm, V. (2007), 'The international business traveller: A neglected but strategic human resource', International Journal of Human Resource Management, $18,2,173-183$.

Wood, S.J., and de Menezes, L.M. (2010), 'Family-firendly management, organizational performance and social legitimacy', International Journal of Human Resource Management, 21, $10,1575-1597$.

Yin, R.K. (2009), Case Study Research: Design and Methods, Thousand Oaks, CA: Sage. 
Table 1: Summary of organisational policy documentation

Company A: Working time and leave policies for international assignments

\begin{tabular}{|c|c|c|c|c|c|}
\hline \multirow[b]{2}{*}{ Policy element } & \multicolumn{5}{|c|}{ Assignment type } \\
\hline & $\begin{array}{c}\text { Long term } \\
\text { (Europe \& USA) }\end{array}$ & $\begin{array}{c}\text { Long term } \\
\text { (Other) }\end{array}$ & $\begin{array}{l}\text { Extended } \\
\text { transfers }\end{array}$ & Short-term & Rotational \\
\hline Maternity/ paternity & $\checkmark$ & $\checkmark$ & & & \\
\hline Working hours & Local & Local & Local & Local & $\checkmark$ \\
\hline Vacation & Home & Home & Local & Home & \\
\hline Travel & $\checkmark$ & $\checkmark$ & $\checkmark$ & $\checkmark$ & $\checkmark$ \\
\hline Home leave & $\checkmark$ & $\checkmark$ & & $\checkmark$ & \\
\hline $\mathrm{R} \& \mathrm{R}$ & & $\checkmark$ & & & \\
\hline Emergencies & $\checkmark$ & $\checkmark$ & Local & $\checkmark$ & $\checkmark$ \\
\hline
\end{tabular}

Company B: Working time and leave policies for international assignments

\begin{tabular}{lllllll}
\hline & & \multicolumn{3}{c}{ Assignment type } \\
Policy element & Long term & Short-term & Single status & Commuter & Rotational & Placements \\
\hline Maternity & $\checkmark$ & $\checkmark$ & & $\checkmark$ & $\checkmark$ & \\
Working hours & $\checkmark$ & $\checkmark$ & $\checkmark$ & $\checkmark$ & $\checkmark$ & Local \\
Vacation & $\checkmark$ & $\checkmark$ & $\checkmark$ & $\checkmark$ & $\checkmark$ \\
Travel & $\checkmark$ & $\checkmark$ & & & & \\
Home leave & & & $\checkmark$ & & \\
Other trips & $\checkmark$ & & & & $\checkmark$ \\
R \& R & $\checkmark$ & & $\checkmark$ & &
\end{tabular}

Company B: Flexible working and work-life balance policies

\begin{tabular}{|c|c|c|c|}
\hline Policy element & Flexible working (Group) & Flexible working (UK) & Work-life balance (UK) \\
\hline Statement of intent & $\checkmark$ & $\checkmark$ & $\checkmark$ \\
\hline Work-life balance & & $\checkmark$ & $\checkmark$ \\
\hline Hours of work & & $\checkmark$ & $\checkmark$ \\
\hline Procedures & & $\checkmark$ & \\
\hline Career development & & $\checkmark$ & \\
\hline Maternity/ paternity & & & $\checkmark$ \\
\hline Parental leave & & & $\checkmark$ \\
\hline Emergency leave & & & $\checkmark$ \\
\hline $\begin{array}{l}\checkmark=\text { included in poli } \\
\text { Local = local conditi } \\
\text { Home }=\text { based on ho } \\
R \& R=\text { rest and rec }\end{array}$ & $\begin{array}{l}\text { y. } \\
\text { ns apply. } \\
\text { ne country. }\end{array}$ & & \\
\hline
\end{tabular}




\section{Table 2: Interviewee Profile}

\begin{tabular}{lcc}
\hline & Company A & Company B \\
\hline HR personnel interviewed & $\mathbf{4}$ & $\mathbf{1 0}$ \\
& & \\
Job responsibility & 1 & 1 \\
International assignments & 1 & 4 \\
Training/learning and development & 1 & 3 \\
Recruitment/resourcing & 1 & 1 \\
Performance management & & 1 \\
HR head of function & &
\end{tabular}

\begin{tabular}{|c|c|c|c|c|}
\hline Assignees interviewed & & 8 & & 18 \\
\hline Job role & $\begin{array}{c}\text { Geo-sciencel } \\
\text { engineering } \\
6\end{array}$ & $\begin{array}{l}\text { Professional/ } \\
\text { non-technical } \\
\quad 2\end{array}$ & $\begin{array}{c}\text { Geo-sciencel } \\
\text { engineering } \\
3\end{array}$ & $\begin{array}{l}\text { Professional/ } \\
\text { non-technical } \\
15\end{array}$ \\
\hline Assignment status & $\begin{array}{c}\text { Accompanied } \\
3\end{array}$ & $\begin{array}{l}\text { Unaccompanied } \\
5\end{array}$ & $\begin{array}{c}\text { Accompanied } \\
10\end{array}$ & $\begin{array}{c}\text { Unaccompanied } \\
8\end{array}$ \\
\hline Location & Home & Host & Home & Host \\
\hline Western Europe & 3 & 2 & 14 & 1 \\
\hline North America & 3 & 1 & 0 & 2 \\
\hline East Asia & 2 & 3 & 0 & 2 \\
\hline Australasia & 0 & 0 & 2 & 3 \\
\hline Central Asia & 0 & 1 & 0 & 4 \\
\hline Caribbean & 0 & 0 & 2 & 1 \\
\hline North Africa & 0 & 1 & 0 & 2 \\
\hline West Africa & 0 & 0 & 0 & 2 \\
\hline Middle East & 0 & 0 & 0 & 1 \\
\hline Assignment type & Current & Previous & Current & Previous \\
\hline Long-term & 7 & 4 & 14 & 7 \\
\hline Short-term & 0 & 0 & 2 & 5 \\
\hline Rotation & 1 & 1 & 2 & 1 \\
\hline Commuter & 0 & 0 & 0 & 1 \\
\hline Extended transfer & 0 & 0 & N/A & N/A \\
\hline
\end{tabular}


Table 3: Weekly hours worked by assignment type

\begin{tabular}{lccccccc}
\hline Assignment type & $\begin{array}{c}\text { Number of } \\
\text { assignees by } \\
\text { assignment type }\end{array}$ & $\begin{array}{c}\text { Number of } \\
\text { responses }\end{array}$ & Mean & $\begin{array}{c}\text { Std. } \\
\text { Dev. }\end{array}$ & Minimum & Maximum & Range \\
\hline $\begin{array}{l}\text { Long-term } \\
\begin{array}{l}\text { Short-term and } \\
\text { graduate placements }\end{array}\end{array}$ & 51 & 50 & 46.86 & 6.069 & 39.0 & 60.0 & 21.0 \\
$\begin{array}{l}\text { Rotational (28 days } \\
\text { on/28 days off shift) }\end{array}$ & 12 & 11 & 46.82 & 5.135 & 40.0 & 55.0 & 15.0 \\
$\begin{array}{l}\text { Extended } \\
\text { international transfer }\end{array}$ & 5 & 5 & 83.80 & 4.604 & 77.0 & 90.0 & 13.0 \\
\end{tabular}


Table 4: Importance of working hours, leave and flexible working

\begin{tabular}{lccccc}
\hline $\begin{array}{l}\text { How important to you were the following issues in relation } \\
\text { to your decision to participate in your current expatriate }\end{array}$ & n & Median & $\begin{array}{c}\text { Very } \\
\text { important } \\
\text { assignment? }\end{array}$ & $\begin{array}{c}\text { Important } \\
\text { Working hours and leave }\end{array}$ & $\begin{array}{c}\text { Not } \\
\text { important } \\
\%\end{array}$ \\
\hline $\begin{array}{l}\text { Working local hours in assignment location } \\
\text { Working additional hours in assignment location }\end{array}$ & 58 & 1.00 & 6.9 & 20.7 & 72.4 \\
$\quad \begin{array}{l}\text { Undertaking international business trips involving extra } \\
\text { hours of work }\end{array}$ & 60 & 1.00 & 4.6 & 23.1 & 72.3 \\
Taking regular periods away from work through a & 19 & 2.00 & 31.6 & 26.3 & 42.1 \\
rotational working pattern & & & & & \\
Taking regular periods away from work through a & 15 & 2.00 & 13.3 & 40.0 & 46.7 \\
commuter assignment & & & & & \\
Home leave & 58 & 3.00 & 63.8 & 24.1 & 12.1 \\
Rest and recreation leave & 35 & 3.00 & 62.9 & 22.9 & 14.3 \\
Being able to take maternity leave & 24 & 3.00 & 62.5 & 12.5 & 25.0 \\
Being able to take parental leave & 20 & 2.00 & 45.0 & 30.0 & 25.0 \\
Partner being able to take paternity leave & 9 & 3.00 & 66.7 & - & 33.3 \\
Flexible working issues & & & & & \\
Being able to work from home & 46 & 1.00 & 17.4 & 30.4 & 52.2 \\
Being able to work flexitime & 44 & 2.00 & 20.5 & 40.9 & 38.6 \\
Being able vary working time to address personal needs & 52 & 2.00 & 23.1 & 53.8 & 23.1 \\
Being able vary working time to address family needs & 34 & 2.00 & 29.4 & 47.1 & 23.5 \\
Being able to take time off for family emergencies & 51 & 3.00 & 62.7 & 35.3 & 2.0 \\
Being able to work part-time & 16 & 1.00 & - & 25.0 & 75.0 \\
Being able to take a job share arrangement & 15 & 1.00 & - & 20.0 & 80.0
\end{tabular}


Figure 1: A model to depict the effect of satisficing, compensating differentials and career compromise on women's participation in expatriation

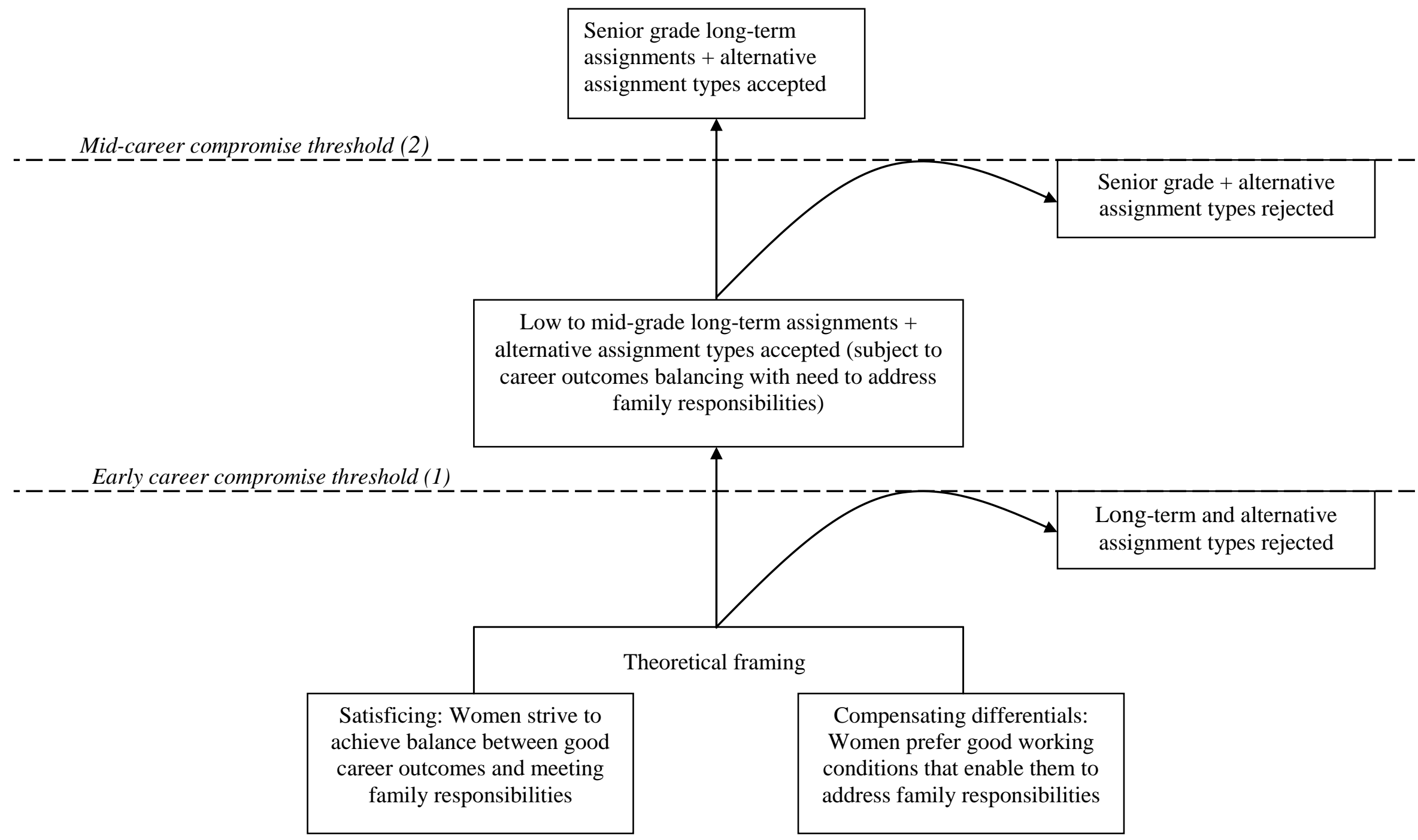

- - - Career compromise threshold = working time/patterns become too onerous to meet family responsibilities and outweigh career benefits from expatriation $\longrightarrow$ Career progression decision 
